\title{
Irrigation Requirements, Root-medium pH, and Nutrient Concentrations of Easter Lilies Grown in Five Peat-based Media with and without an Evaporation Barrier
}

\author{
William R. Argo ${ }^{1}$ and John A. Biernbaum ${ }^{2}$ \\ Department of Horticulture, Michigan State University, East Lansing, MI 48824-1325
}

\begin{abstract}
Additional index words. evaporation, Lilium longiflorum, soluble salts, subirrigation
Abstract. Subirrigated Easter lilies were grown in five commercially formulated root media using one water-soluble fertilizer applied independently to each medium based on water-holding capacity and water loss. The number of irrigations ranged from 12 to 20 and the amount of applied water ranged from 5.3 to 6.8 liters for the uncovered media treatments. When the root-medium surface was covered with an evaporation barrier, the average amount of applied water was reduced by $35 \%$ compared to the uncovered media. The largest effect on root media pH was between uncovered and covered media due to the reduced amount of water applied. Similar macronutrient concentrations were measured in the five media during the experiment with few exceptions. The greatest differences in nutrient concentrations were found within the pots. The top $2.5 \mathrm{~cm}$ (top layer) contained nutrient concentrations up to 10 times higher than those measured in the remaining root medium (root zone) of the same pot. Covering the root-medium surface with an evaporation barrier reduced the stratification of fertilizer salts. Root-zone soluble salt concentrations of plants in the covered pots were similar to those of uncovered plants even though $36 \%$ less fertilizer was applied to the covered plants.
\end{abstract}

Environmental concerns regarding nitrate and phosphate runoff have made using high concentrations of water-soluble fertilizer (WSF) and high leaching rates to manage root-media nutrient levels unacceptable (Biernbaum, 1992). The relationship between WSF concentration and leaching on media nutrient concentrations has been documented for container-grown greenhouse crops (Hasek et al., 1986; Ku and Hershey, 1991; Yelanich and Biernbaum, 1993). As the leaching fraction decreases, medium nutrient concentrations increase unless the WSF concentration applied also decreases.

Nutritional problems continue to exist in producing greenhouse crops using nonleaching irrigation systems and lower WSF concentrations. Factors other than leaching, such as cation exchange capacity (CEC), water-holding capacity, and evaporative water loss, may also affect nutrient availability. As leaching fractions decrease, the relative importance of these media-related factors increases. The effect of these media-related factors on crop water use, medium $\mathrm{pH}$, and nutrient concentrations also needs to be studied under nonleaching conditions.

CEC provides a nutrient reserve and buffers the medium from sudden changes in nutrient concentration and $\mathrm{pH}$ (Bunt, 1988; Nelson, 1991). The CEC of peat is due to organic acids that are formed from the degradation of lignins in the plant cell wall (Puustjarvi and Robertson, 1975). Puustjarvi (1983) reported a linear relationship between the degree of decomposition of peat as measured by the von Post scale and the CEC (in meq.liter ${ }^{-1}$ ). The more degraded the peat, the greater the amount of organic acids and the higher the CEC. It has been proposed that the more-degraded peats may slow the increases in medium $\mathrm{pH}$ caused by irrigation

Received for publication 20 Dec. 1993. Accepted for publication 3 June 1994. We acknowledge the Michigan Agricultural Experiment Station (MAES) and the American Floral Endowment for supporting this research. Plant tissue analysis was provided by the Grace Sierra Co., Allentown, Pa. The use of trade names in this publication does not imply endorsement by the MAES of the products named nor criticism of similar ones not mentioned. The cost of publishing this paper was defrayed in part by the payment of page charges. Under postal regulations, this paper therefore must be hereby marked advertisement solely to indicate this fact ${ }^{1}$ Graduate research assistant.

${ }^{2}$ Associate professor. water with high concentrations of bicarbonate alkalinity (Biernbaum, 1992; Bunt,1988). Pine or hardwood bark and vermiculite also contribute to nutrient retention but are not commonly present in greenhouse root media at the same high percentages as peat (Bunt, 1988; Nelson, 1991). Therefore, the main difference in the buffering capacity of peat-based root media may be the degradation state and quantity of peat used to produce the media.

Other root-medium components, such as perlite, polystyrene, or rockwool, have little or no CEC and are included in peat-based root media primarily to increase aeration or water-holding capacity (Nelson, 1991). Few controlled comparisons of peat-based root media have been made with each medium irrigated independently to provide a constant leaching fraction or water-holding capacity. Under constant liquid fertilization and scheduled irrigations with no leaching, medium water-holding capacity may influence fertilization frequency and medium nutrient concentrations.

Evaporation of water from the root-medium surface can also affect root-media nutrition. Laurie and Ries (1950) noted the large amount of water lost by peat because of surface evaporation. Peat fibers act as a wick, moving the internal moisture by capillarity to the surface where evaporation is most rapid. The amount of water lost from the pot via evaporation from the root-medium surface is $\approx 25 \%$ to $30 \%$ of the total water loss (Furuta et al., 1977; Van de Werken, 1989).

Evaporation from the root-medium surface leads to the accumulation of fertilizer salts at the top of the pot (Guttormsen, 1969). Nelson (1991) recommends excluding the top $1 \mathrm{~cm}$ of root medium in a pot or bed when collecting medium samples for analysis because of the presence of abnormally high concentrations of fertilizer salts. Havis (1982) conducted an experiment with resincoated fertilizer (RCF) during which some of the containers were covered with a fiberglass disk. In the containers with an evaporation barrier (EB), a lower electrical conductivity (EC) was measured in the top $10-\mathrm{cm}$ of the root medium and a higher EC was measured in the rest of the container compared to that in containers without the EB. The decreased quality of azaleas grown in containers with the EBs at a high $\mathrm{RCF}$ incorporation rate $\left(3.0 \mathrm{~kg} \cdot \mathrm{m}^{-3}\right)$ was attributed to reduced salt stratification.

One objective of this research was to monitor root-medium $\mathrm{pH}$, 
EC, nutrient concentrations, and water use in subirrigated Easter lilies grown in root media that varied in peat type and waterholding capacity. The second objective was to quantify evaporation from the root-medium surface and its affect on media $\mathrm{pH}$, nutrient concentrations, and water use.

\section{Materials and Methods}

The treatments were arranged as a randomized complete block with five root media, two cover treatments, two blocks, and six plants per block for a total of 120 pots. One plant from each treatment was selected per block for media sampling at each sampling date. Data were analyzed as a $5 \times 2$ factorial at each sampling date using SAS's analysis of variance (ANOVA) procedures (SAS Institute, 1982). Time was not included as a factor in the ANOVA because sample variance increased over time.

The root media used in this experiment were 1) Suremix Rockwool Mix (SRM) composed of Canadian sphagnum peat, medium-grind rockwool (Partek North American, Brunswick, Ohio), and no. 3 vermiculite with limestone and a preplant nutrient charge (PNC) (Michigan Growers Products, Galesburg, Mich.); 2) Metro Mix 510 (MM 510), composed of Canadian sphagnum peat, no. 3 vermiculite, composted pine bark, bark ash, and sand with limestone and a PNC (Grace Sierra, Fogelsville, Pa.); 3) Postharvest Mix (PHM) composed of Canadian sphagnum peat, perlite, calcined clay, and a superabsorbent gel with limestone and a PNC (Fisons Western Corp., Downers Grove, Ill.); 4) Al-par Planting Mix (APM) composed of field-harvested organic muck, Canadian sphagnum peat, and polystyrene with limestone and a PNC (Al-par Peat Co., Ovid, Mich.); and 5) Baccto Professional Growers Mix (BPGM), composed of Michigan sphagnum peat, vermiculite, and perlite with limestone and a PNC (Michigan Peat Co., Houston).

The types of peat used in media 1, 2, and 3 were long-fibered sphagnum peat with little dust (von Post scale 1 to 2 ). The peat used in medium 5 was a short-fibered, more-degraded sphagnum peat with a large amount of dust (von Post scale 2 to 3). Medium 4 contained a long-fibered sphagnum peat with little dust and a highly degraded reed-sedge peat muck that, when dry, was primarily dust (von Post scale $>5$ ).

The second factor examined in this experiment was the effect of evaporation from the root-medium surface. An EB was made from a $15-\mathrm{cm}$ plastic saucer that was placed over the root-medium surface of half the pots at planting (covered pots). When the plant emerged from the root medium, a hole was placed in the saucer for the plant to grow through.

The experiment was conducted at Michigan State Univ., East Lansing, in a well-ventilated glasshouse with constant air circulation and cement floors. Case-cooled Lilium longiflorum 'Nellie White' bulbs were planted into 15 -cm-tall $\times 15$-cm-wide (1.7-liter) plastic pots on 19 Dec. 1989.

Plants were subirrigated with tap water from planting until 18 Jan. 1990. Each root medium was treated independently. The amount of water available for the root media was estimated in a previous experiment. The time to water was determined gravimetrically when the average daily weight of six plants reached a target weight based on a loss of $70 \%$ to $80 \%$ of the available water. The target weight was $1100 \mathrm{~g}$ for plants grown in the APM and 800 $\mathrm{g}$ for all other root media and did not change during the experiment. A plastic saucer was placed under each of the pots, and a volume of solution that could be absorbed in 30 min was placed in each saucer. The amount applied was determined for each root medium based on its water-holding capacity. At each irrigation, 0.45 liter was applied to plants grown in SRM, 0.35 liter was applied to MM
510 and PHM, and 0.30 liter was applied to BPGM and APM.

The water used in this experiment had an EC of $0.6 \mathrm{dS} \cdot \mathrm{m}^{-1}$ and an alkalinity to $\mathrm{pH} 4.0$ of $310 \mathrm{mg} \mathrm{CaCO} / \mathrm{liter}, 2.0 \mathrm{~mol} \cdot \mathrm{m}^{-3} \mathrm{Ca}^{2+}, 1.6$ $\mathrm{mol} \cdot \mathrm{m}^{-3} \mathrm{Mg}^{2+}$, and $1.0 \mathrm{~mol} \cdot \mathrm{m}^{-3} \mathrm{Na}^{+}$. Starting $19 \mathrm{Jan}$., WSF solution with $7.1 \mathrm{~N}-0 \mathrm{P}-2.1 \mathrm{~K}\left(\mathrm{~mol} \cdot \mathrm{m}^{-3}\right)$ from $\mathrm{Ca}\left(\mathrm{NO}_{3}\right)_{2}$ and $\mathrm{KNO}_{3}$ plus a source of minor nutrients (Compound 111, Peter's Fertilizer, Fogelsville, Pa.) was applied at every irrigation. After 21 Feb., the concentration of the WSF solution was increased to $14.2 \mathrm{~N}-2.3 \mathrm{P}$ $4.1 \mathrm{~K}\left(\mathrm{~mol} \cdot \mathrm{m}^{-3}\right)$ plus minor nutrients. Phosphorous was supplied by adding $2.3 \mathrm{~mol} \cdot \mathrm{m}^{-3}$ of phosphoric acid to the fertilizer solution to neutralize $3.2 \mathrm{~mol} \cdot \mathrm{m}^{-3}$ of the alkalinity in the irrigation water and to control root-media $\mathrm{pH}$.

Root-media samples were collected from two pots about every 3 weeks starting 30 Jan. The top $2.5 \mathrm{~cm}$ (top layer) was removed and sampled separately from the rest of the medium (root zone). Nutrients in the root media were sampled using the saturated media extraction (SME) technique (Warncke, 1986) with reverse-osmosis purified water as the extractant. Root-media $\mathrm{pH}$ was measured in the saturated media before extraction. EC was determined using a platinum electrode at a standard $25 \mathrm{C}$. Nitrate $\mathrm{N}$ was determined with a nitrate-specific electrode. The ions $\mathrm{K}^{+}, \mathrm{Ca}^{2+}, \mathrm{Mg}^{2+}$, and $\mathrm{Na}^{+}$ were determined by flame emission, and $\mathrm{PO}_{4}-\mathrm{P}$ was determined colorimetrically by the ascorbic acid method (Knudsen and Beegle, 1988). Shoot height and leaf number were determined for six plants per treatment at anthesis.

On 14 Apr., six plants from each treatment were moved into a simulated postproduction environment that consisted of a laboratory with a 24-h average photosynthetic photon flux of 0.67 $\mathrm{mol} \cdot \mathrm{m}^{-2}$ from cool-white fluorescent lamps and a constant $22 \mathrm{C}$. The root media were irrigated to near container capacity and allowed to dry. The plants and pots were weighed every 2 days for 16 days to determine the total amount of water loss. On 8 May, the top 10 leaves were removed from each plant for elemental analysis.

\section{Results and Discussion}

Applied water and fertilizer. The number of irrigations ranged from 12 to 20 and the amount of water applied ranged from 5.32 to 6.80 liters for the uncovered treatments (Table 1). The plants grown in the uncovered APM media were irrigated more times and received 1 liter more of water than the other treatments (15\% more than the next largest volume treatment).

A major concern greenhouse operators have when using root media with high water-holding capacities involves the long time between WSF applications. It is assumed that if WSF is not applied frequently or the concentration is not changed, nutrients will become limiting. For a given concentration, the amount of WSF applied is a function of the number of applications and the amount of solution applied. For example, uncovered plants grown in SRM required $40 \%$ fewer irrigations than those grown in APM (12 vs. 20). However, plants grown in SRM received only $14 \%$ less $\mathrm{N}$ fertilizer $(0.14 \mathrm{~g} \mathrm{~N})$ than those grown in APM because SRM received $33 \%$ more water and WSF at any single irrigation. Thus, reducing the number of fertilizations in high water-holding capacity media is compensated for, to a certain extent, by increasing the volume of WSF applied at each irrigation. Similar results were obtained by Argo (1993) with top-watered poinsettias and Argo and Biernbaum (1993) with hanging baskets in a simulated postproduction environment.

In the covered pots, averaged over all root media, there was a $35 \%$ reduction in the number of irrigations and the total amount of water applied compared to the uncovered pots (Table 1). The range was from $50 \%$ less water applied for plants grown in SRM to $22 \%$ 
Table 1. Irrigation number (IN), amount of applied water (AW) and N fertilizer (ANF), postproduction water use (PWU), plant growth characteristics (shoot height and number of leaves), and leaf nutrient concentrations at 20 weeks for Easter lily grown without or with an evaporation barrier (EB) in five root media from 19 Dec. 1989 to 14 Apr. 1990.

\begin{tabular}{|c|c|c|c|c|c|c|c|c|c|c|c|c|}
\hline \multirow[b]{2}{*}{$\begin{array}{l}\text { Root } \\
\text { medium }^{w}\end{array}$} & \multirow[b]{2}{*}{ IN } & \multirow[b]{2}{*}{$\begin{array}{c}\mathrm{AW}^{\mathrm{z}} \\
\text { (liters) }\end{array}$} & \multirow[b]{2}{*}{$\begin{array}{c}\mathrm{ANF}^{\mathrm{z}} \\
(\mathrm{g})\end{array}$} & \multicolumn{3}{|c|}{ Shoot } & \multicolumn{6}{|c|}{ Leaf nutrient concn } \\
\hline & & & & $\begin{array}{l}\text { PWU }^{y} \\
\text { (liters) }\end{array}$ & $\begin{array}{l}\mathrm{ht}^{\mathrm{x}} \\
(\mathrm{cm})\end{array}$ & $\begin{array}{c}\text { Leaves } \\
\text { (no.) }\end{array}$ & $\mathrm{N}$ & $\mathrm{P}$ & $\begin{array}{c}\mathrm{K} \\
\left(\mathrm{mol} \cdot \mathrm{kg}^{-}\right.\end{array}$ & $\begin{array}{c}\mathrm{Ca} \\
\text { ry mass }\end{array}$ & $\mathrm{Mg}$ & $\mathrm{Na}$ \\
\hline \multicolumn{13}{|c|}{ Uncovered } \\
\hline SRM & 12 & 5.83 & 0.84 & 0.39 & 45.1 & 94 & 2.20 & 0.15 & 1.10 & 0.28 & 0.30 & 0.02 \\
\hline MM 510 & 15 & 5.92 & 0.87 & 0.40 & 53.6 & 91 & 2.23 & 0.18 & 1.08 & 0.34 & 0.28 & 0.02 \\
\hline PHM & 14 & 5.54 & 0.90 & 0.45 & 48.3 & 82 & 2.41 & 0.24 & 1.11 & 0.38 & 0.33 & 0.07 \\
\hline APM & 20 & 6.80 & 0.98 & 0.36 & 48.7 & 86 & 2.17 & 0.09 & 1.04 & 0.39 & 0.29 & 0.02 \\
\hline BPGM & 16 & 5.32 & 0.95 & 0.35 & 48.9 & 84 & 2.24 & 0.15 & 1.13 & 0.28 & 0.34 & 0.03 \\
\hline \multicolumn{13}{|c|}{ Covered with EB } \\
\hline SRM & 6 & 2.93 & 0.47 & 0.17 & 42.6 & 81 & 2.09 & 0.17 & 1.02 & 0.33 & 0.37 & 0.04 \\
\hline MM 510 & 10 & 3.76 & 0.52 & 0.22 & 49.0 & 91 & 2.35 & 0.21 & 1.10 & 0.35 & 0.30 & 0.02 \\
\hline PHM & 10 & 3.62 & 0.60 & 0.20 & 44.3 & 82 & 2.24 & 0.21 & 1.03 & 0.35 & 0.27 & 0.14 \\
\hline APM & 12 & 4.08 & 0.66 & 0.20 & 46.8 & 88 & 2.33 & 0.10 & 0.93 & 0.42 & 0.30 & 0.02 \\
\hline BPGM & 12 & 4.15 & 0.71 & 0.22 & 45.9 & 82 & 2.28 & 0.19 & 1.10 & 0.30 & 0.38 & 0.02 \\
\hline \multicolumn{13}{|c|}{ Significance } \\
\hline Medium (M) & $* * *$ & $* *$ & $* *$ & $* *$ & $* * *$ & $*$ & NS & $* * *$ & NS & $* * *$ & $* * *$ & $* * *$ \\
\hline $\mathrm{EB}$ & $* * *$ & $* * *$ & $* * *$ & $* * *$ & $* * *$ & NS & NS & NS & NS & NS & $*$ & $* * *$ \\
\hline $\mathrm{M} \times \mathrm{EB}$ & $*$ & $*$ & $*$ & $* *$ & NS & NS & NS & NS & NS & NS & $* *$ & $* * *$ \\
\hline
\end{tabular}

${ }^{\mathrm{z}} \mathrm{AW}$ and $\mathrm{ANF}$ are reported on a per-pot basis.

yPWU was calculated for the first 8 days in the postproduction environment.

${ }^{x}$ Shoot height was measured from the rim of the pot to the topmost flower bud at anthesis of the first flower.

${ }^{\mathrm{w}} \mathrm{SRM}=$ Suremix Rockwool Mix, MM $510=$ Meto Mix 510, PHM = Postharvest Mix, APM = Al-par Planting Mix, BPGM = Baccto Professional Growers Mix.

Ns,*,**,**** Nonsignificant or significant at $P \leq 0.05,0.01$, or 0.001 , respectively.

less water applied for plants grown in BPGM. These values are consistent with previous reports (Furuta et al., 1977; Van de Werken, 1989). In the postproduction environment, water loss of plants with the EB ranged from 56\% less for PHM and SRM to 37\% less for BPGM than for the same uncovered treatments over a 10day drying cycle.

Media $\mathrm{pH}$. Initial root-media $\mathrm{pH}$ varied from 6.1 to 6.6. In the uncovered pots, the root-zone $\mathrm{pH}$ was $>7.0$ by day 63 , at which time phosphoric acid was added to the irrigation water (Fig. 1, Table 2). After acid was added to the fertilizer solution, root-zone $\mathrm{pH}$ decreased until the end of the experiment.

In the uncovered pots, BPGM containing a more-degraded sphagnum peat buffered root-zone $\mathrm{pH}$ for the first 42 days. However, APM containing highly degraded peat muck did not buffer the root-zone $\mathrm{pH}$ as expected. Instead, MM 510 had a $\mathrm{pH}$ buffering capacity similar to that of BPGM at sampling dates 42 to the end of the experiment. MM 510 was the only medium containing pine bark, bark ash, and vermiculite as the other primary components. It seems that the $\mathrm{pH}$ buffering capacity of a root medium cannot be predicted from the von Post scale rating of the peat used to produce the media. This subject requires further investigation.

Covering the medium surface with an $\mathrm{EB}$ resulted in a $\mathrm{pH}$ lower than that of the uncovered plants on days 42, 63, and 86 (Fig. 1, Table 2). By reducing the irrigation frequency (Table 1), the EB decreased the amount of bicarbonate applied to the root media. However, once the lilies began to grow and were irrigated more, the $\mathrm{pH}$ increased to unacceptable levels in all root media. The differences in root-zone $\mathrm{pH}$ after day 63 in the uncovered pots vs. the covered pots were probably due to the application of more acidified irrigation water.

Medium root-zone nutrient concentrations. Large differences in macronutrient retention by the five media as measured by rootzone EC were not observed (Fig. 1, Table 2). After the initial media analysis, root-zone macronutrient concentrations decreased at about the same rate in all five root media (Fig. 1). Data are presented for $\mathrm{NO}_{3}-\mathrm{N}$ and $\mathrm{Mg}^{2+}$. There were limited treatment effects for $\mathrm{K}^{+}$and $\mathrm{PO}_{4}-\mathrm{P}$ (Table 2 ), and the changes in nutrient concentration over time resembled that of $\mathrm{NO}_{3}-\mathrm{N}$. Calcium concentrations were similar to those of $\mathrm{Mg}^{2+}$ (data not shown).

Once liquid fertilizer concentrations were increased after day 63 , nutrient concentrations increased at about the same rate in all media. The root medium with the most-degraded peat (APM) had the fastest increase in root-zone nutrient levels. However, the increase in root-zone EC of APM was probably because of the greater amounts of water and WSF applied (Table 1) and not the buffering properties of the medium.

It may be important to note the these conclusions are based on a SME with water. Water SME has been shown to be well correlated with plant growth and nutrient availability in peat-based media (Warncke and Krauskopf, 1983). However, the concentration of some elements may be different with other extractants.

Medium nutrient stratification. Soluble salt concentrations in the top $2.5 \mathrm{~cm}$ of all root media were several times higher than in the root zone (Fig. 2), as previously reported for subirrigation (Guttormsen, 1969). The top layer of subirrigated pots acted as a point of fertilizersalt removal from the root zone. We conclude that this process is similar to removing salts from the root zone by leaching.

The stratification of fertilizer salts did not start in the covered pots until after shoot emergence, at which time a hole was placed in the cover. The difference in EC between the top layer and the root zone of covered plants was not $>1.5 \mathrm{dS} \cdot \mathrm{m}^{-1}$ compared to a maximum difference between the top layer and root zone of 4.9 $\mathrm{dS} \cdot \mathrm{m}^{-1}$ for the uncovered pots. 


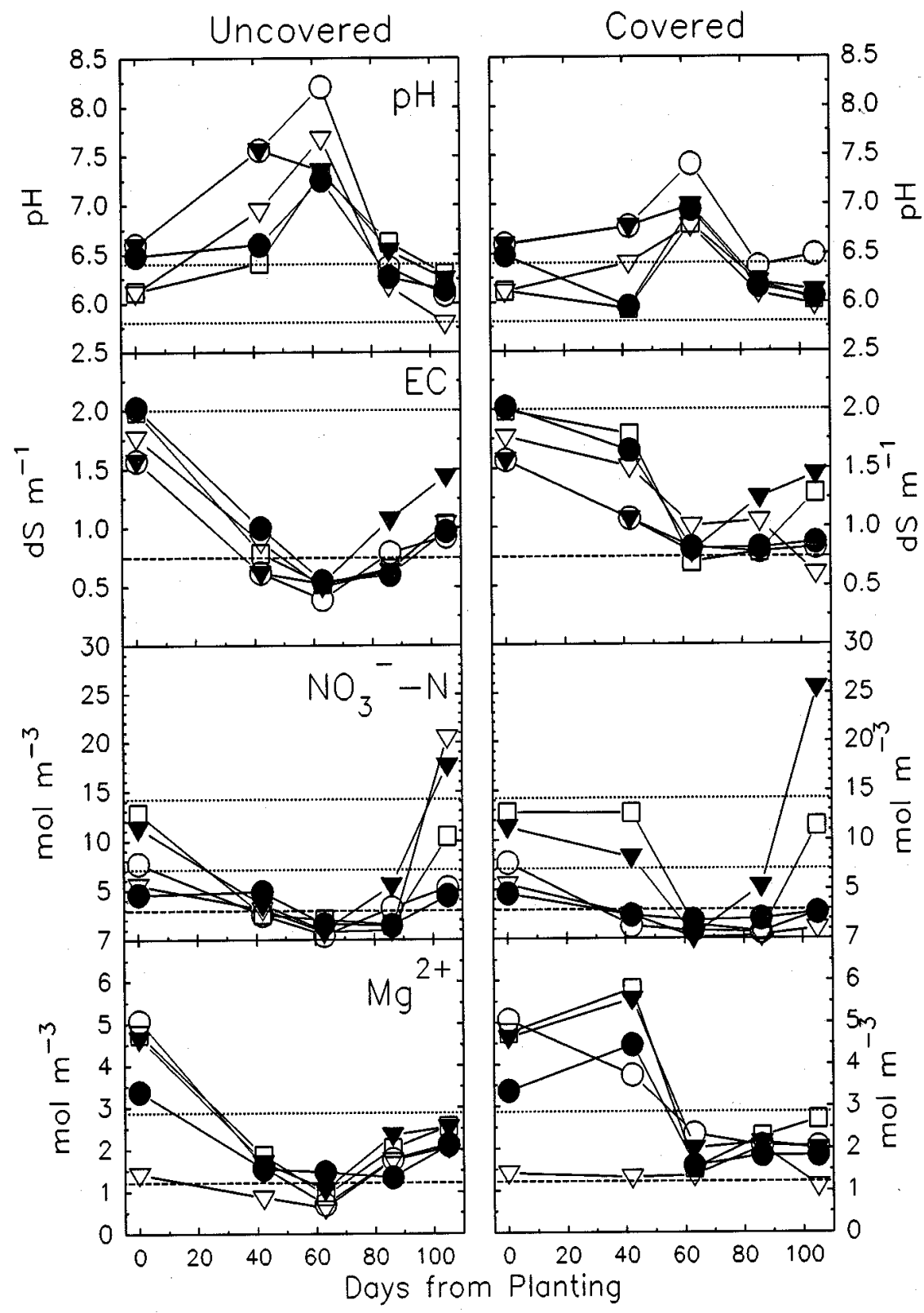

Fig. 1. Root zone medium $\mathrm{pH}$, electrical conductivity (EC), $\mathrm{NO}_{3}^{--} \mathrm{N}$, and $\mathrm{Mg}^{2+}$ concentrations for subirrigated Easter lily grown in five root media without

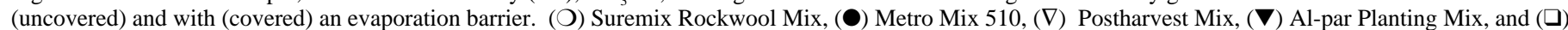
Baccto Professional Growers Mix. Dotted lines indicate the recommended optimal ranges and lower diasked lines represent the recommended acceptable ranges for the saturated medium extraction technique (Warncke and Krauskopf, 1983).

At day 42 and 63, the root-zone EC was higher in media covered with an EB compared to the uncovered pots (Fig. 2, Table 2). The covered pots had only been watered once with clear water, while the uncovered pots had been watered twice with clear water and fertilized three times with the $7.2 \mathrm{~mol} \cdot \mathrm{m}^{-3} \mathrm{~N}$ fertilizer solution. For the rest of the experiment, root-zone $\mathrm{EC}$ was similar in the covered and uncovered pots. Thus, by reducing fertilizer-salt stratification with the barrier, $35 \%$ less water and fertilizer was required to maintain root-zone nutrient concentrations similar to those in the uncovered pots.

Another example of how salt stratification within the pot affected root-zone nutrient availability can be demonstrated with the $\mathrm{Na}^{+}$medium analysis data. Top-layer and root-zone $\mathrm{Na}^{+}$ concentrations were higher in PHM than in the other media on all sampling dates (Fig. 3, Table 3). In the top layer, $\mathrm{Na}^{+}$concentra- tions were greater in the uncovered pots than the covered pots, but the difference was greater with PHM than with the other media at each sampling date. In the root zone, $\mathrm{Na}^{+}$concentrations were lower in the uncovered PHM than the covered PHM on sampling date 42 (4.7 vs. $9.3 \mathrm{~mol} \cdot \mathrm{m}^{-3}$, respectively) and 63 (1.6 vs. 4.8 $\mathrm{mol} \cdot \mathrm{m}^{-3}$, respectively).

Elevated concentrations of leaf $\mathrm{Na}$ were present in plants grown in the uncovered PHM $\left(0.07 \mathrm{~mol} \cdot \mathrm{kg}^{-1}\right.$ dry mass $)$ compared to that of plants grown in the other uncovered root media (average 0.02 $\mathrm{mol} \cdot \mathrm{kg}^{-1}$ dry mass) (Table 1 ). Leaf Na was higher in plants grown in covered PHM ( $0.14 \mathrm{~mol} \cdot \mathrm{kg}^{-1}$ dry mass) than in uncovered PHM.

Plant growth and tissue analysis. Plant height varied $11 \mathrm{~cm}$ (20\%) and leaf number varied by $13(14 \%)$ (Table 1), but all plants were of marketable quality at flowering. Shoot height was reduced by the EB but leaf number was not affected. 
Table 2. Summary of analysis of variance from the root zone for root-medium $\mathrm{pH}$, electrical conductivity (EC), and nutrient concentration by sampling date.

\begin{tabular}{|c|c|c|c|c|c|c|}
\hline & & \multicolumn{5}{|c|}{ Days after planting } \\
\hline & & 0 & 42 & 63 & 86 & 105 \\
\hline \multirow[t]{3}{*}{$\overline{\mathrm{pH}}$} & Medium $(\mathrm{M})$ & $* *$ & $* * *$ & $* *$ & NS & $* *$ \\
\hline & Evaporation barrier (EB) & --- & $* * *$ & $* * *$ & $*$ & NS \\
\hline & $\mathrm{M} \times \mathrm{EB}$ & --- & NS & NS & NS & $* *$ \\
\hline \multirow[t]{3}{*}{$\mathrm{EC}$} & M & $* *$ & $*$ & NS & NS & $* *$ \\
\hline & EB & --- & $* * *$ & $*$ & NS & NS \\
\hline & $\mathrm{M} \times \mathrm{EB}$ & --- & NS & NS & NS & NS \\
\hline \multirow{3}{*}{$\mathrm{NO}_{3}^{-}-\mathrm{N}$} & M & $* * *$ & $* * *$ & NS & NS & $* * *$ \\
\hline & EB & --- & $* *$ & NS & NS & $*$ \\
\hline & $\mathrm{M} \times \mathrm{EB}$ & --- & $* * *$ & NS & NS & $* * *$ \\
\hline \multirow[t]{3}{*}{$\mathrm{PO}_{4}-\mathrm{P}$} & M & $* *$ & $* * *$ & $* * *$ & NS & NS \\
\hline & EB & --- & $*$ & NS & NS & NS \\
\hline & $\mathrm{M} \times \mathrm{EB}$ & --- & NS & NS & NS & NS \\
\hline \multirow[t]{3}{*}{$\mathrm{K}+$} & M & $* * *$ & $*$ & NS & NS & NS \\
\hline & EB & --- & NS & NS & NS & NS \\
\hline & $\mathrm{M} \times \mathrm{EB}$ & --- & NS & NS & NS & NS \\
\hline \multirow[t]{3}{*}{$\mathrm{Ca}^{2+}$} & M & $* * *$ & $* *$ & NS & $*$ & $* * *$ \\
\hline & EB & --- & $* * *$ & $*$ & NS & NS \\
\hline & $\mathrm{M} \times \mathrm{EB}$ & --- & NS & NS & NS & NS \\
\hline \multirow[t]{3}{*}{$\mathrm{Mg}^{2+}$} & M & $* * *$ & $* * *$ & NS & NS & $* *$ \\
\hline & EB & --- & $* * *$ & NS & NS & $*$ \\
\hline & $\mathrm{M} \times \mathrm{EB}$ & --- & $* * *$ & NS & NS & NS \\
\hline
\end{tabular}

$\overline{\mathrm{Ns}}^{*, * *, * * * *}$ Nonsignificant or significant at $P \leq 0.05,0.01$, or 0.01 , respectively.

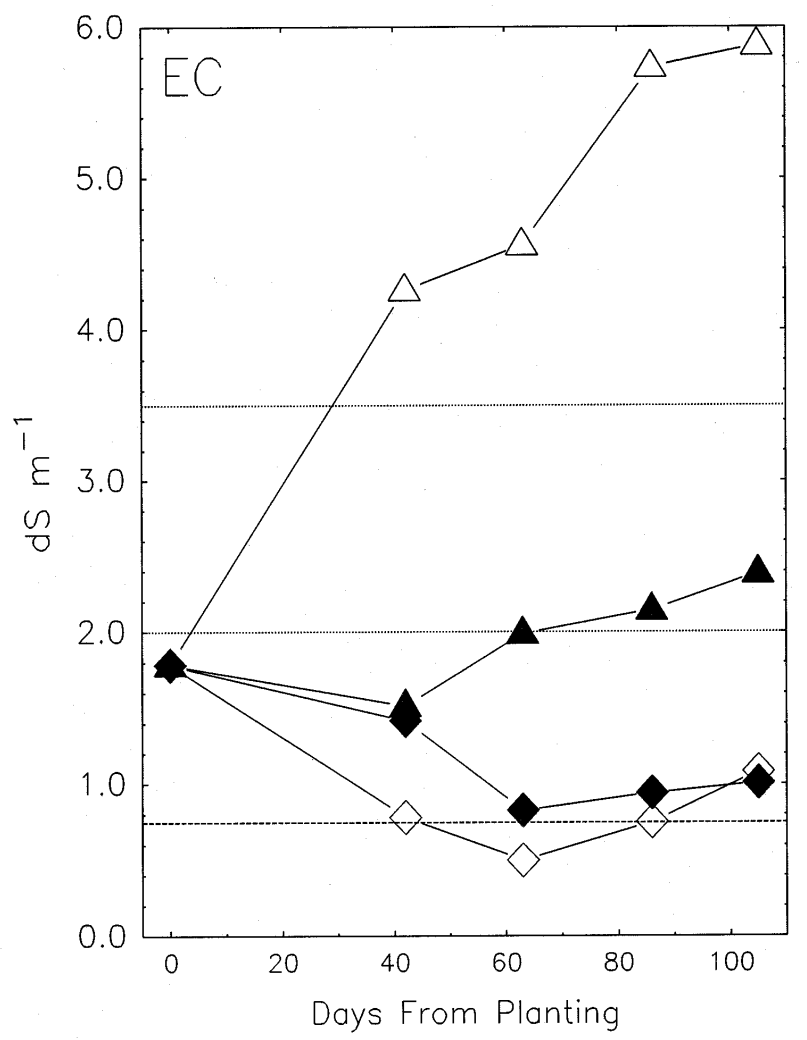

Fig. 2. Comparison of root-zone and top-layer electrical conductivity (EC) with Easter lilies grown without (uncovered) or with (covered) an evaporation barrier. $(\Delta)$ Uncovered top layer, $(\boldsymbol{\Delta})$ covered top layer, $(\diamond)$ uncovered root zone, $(\diamond)$ covered root zone. Each value is averaged over five root media from each treatment. Dotted lines indicate the recommended optimal range and lower dashed lines represent the recommended acceptable ranges for the saturated medium extraction technique (Warncke and Krauskopf, 1983).
The concentration of macronutrients (S not analyzed) in the 10 mature leaves at the top of the plant were within acceptable ranges in all five media. Lily leaf $\mathrm{N}$ and $\mathrm{K}$ concentrations were similar in all media (Table 1). Leaf $\mathrm{P}$ was lower and $\mathrm{Ca}$ was higher in the APM plants, a result that is consistent with the low concentration of $\mathrm{P}$ measured in the root-media analysis early in the crop. Magnesium was the only macronutrient in the leaf tissue influenced by the EB, but treatment concentration means only ranged from 0.27 to $0.38 \mathrm{~mol} \cdot \mathrm{kg}^{-1}$.

\section{Conclusion}

With nonleaching systems, it cannot be assumed that the applied fertilizer will remain in the root zone available to the plant since evaporation-driven fertilizer-salt movement to the rootmedium surface is occurring. For the five media tested, media chemical properties had less of an effect on $\mathrm{pH}$ and nutrient management than medium water-holding capacity and evaporation from the root-medium surface. More research is needed to optimize nutrient management strategies for nonleaching systems including top-watering methods and careful selection of media treatments with similar starting nutrient concentrations. Further testing with WSF at higher concentrations is needed to determine if reduced fertilizer-salt stratification increases root-zone nutrient levels and reduces plant growth as reported by Havis (1982).

\section{Literature Cited}

Argo, W.R. 1993. The role of peat-based root media in water and nutrient efficiency of greenhouse crops. MS thesis. Michigan State Univ., East Lansing.

Argo, W.R. and J.A. Biernbaum. 1993. Factors affecting garden performance of flowering plants in hanging baskets. Bedding Plant Foundation Res. Rpt. F-061 and F-061A.

Biernbaum, J.A. 1992. Root-zone management of greenhouse container- 

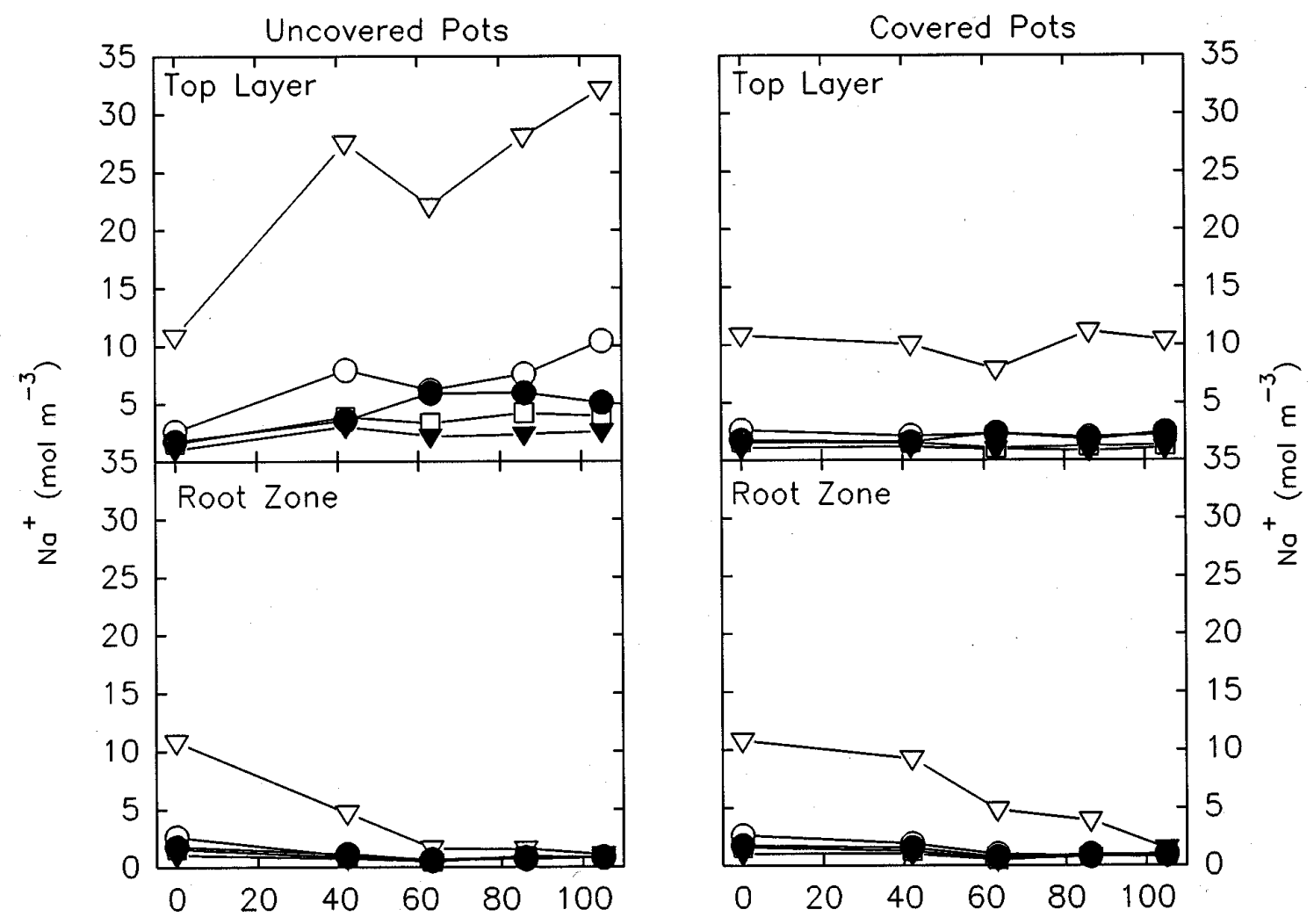

Fig. 3. Comparasion of top-layer and root-zone $\mathrm{Na}^{+}$concentrations of lilies grown in pots with and without an evaporation barrier. (O) Suremix Rockwool Mix, Metro Mix 510, ( $\nabla)$ Postharvest Mix, ( $)$ Al-par Planting Mix, and ( $\square$ ) Baccto Professional Growers Mix.

Table 3. Analysis of variance for root-medium $\mathrm{Na}$ concentrations in the top layer and root zone by sampling date.

\begin{tabular}{|c|c|c|c|c|c|}
\hline & \multicolumn{5}{|c|}{ Days after planting } \\
\hline & 0 & 42 & 63 & 86 & 105 \\
\hline \multicolumn{6}{|c|}{ Top layer } \\
\hline Medium (M) & $* * *$ & $* * *$ & $* * *$ & $* * *$ & $* * *$ \\
\hline $\mathrm{EB}^{\mathrm{z}}$ & --- & $* *$ & $* * *$ & $* * *$ & $* * *$ \\
\hline $\mathrm{EB} \times \mathrm{M}$ & --- & NS & $* * *$ & $* *$ & $* * *$ \\
\hline \multicolumn{6}{|c|}{ Root zone } \\
\hline M & $* * *$ & $* * *$ & $* *$ & $* *$ & $*$ \\
\hline $\mathrm{EB}$ & --- & $* *$ & $*$ & NS & $*$ \\
\hline $\mathrm{EB} \times \mathrm{M}$ & --- & $*$ & $*$ & NS & NS \\
\hline
\end{tabular}

${ }^{\mathrm{Z}}$ Evaporation barrier.

Ns,*,**,****Nonsignificant or significant at $P \leq 0.05,0.01$, or 0.001 , respectively.

grown crops to control water and fertilizer use. HortTechnology 2:127132.

Bunt, A.C. 1988. Media and mixes for container-grown plants. 2nd ed. Unwin Hyman, London.

Furuta, T., T. Mock, and R. Coleman. 1977. Estimating the water needed for container-grown nursery stock. Amer. Nurseryman 145(8):68.

Guttormsen, G. 1969. Accumulation of salts in the subirrigation of pot plants. Plant and Soil 31(3):425-438.

Hasek, R.F., R.H. Sciaroni, and R.L. Branson. 1986. Water conservation and recycling in ornamental production. HortScience 21:35-38.
Havis J.R. 1982. Applying slow-release fertilizer in container nurseries with capillary watering. Amer. Nurseryman 156(4):24-32.

Knudsen, D. and D. Beegle. 1988. Recommended phosphorus tests, p. 12 15. In: W.C. Dahnke (ed.). Recommended chemical soil test procedures for the north central region. North Central Regional Publ. no. 221.

$\mathrm{Ku}$, C.S.M. and D.R. Hershey. 1991. Leachate electrical conductivity and growth of potted poinsettia with leaching fractions of 0 to 0.4 . J. Amer. Soc. Hort. Sci. 116:802-806.

Laurie, A. and V.H. Ries. 1950. Floriculture. Fundamentals and practices. 2nd ed. McGraw-Hill, New York. p. 32-35.

Nelson. P.V. 1991. Greenhouse operation and management. 4th ed. Reston Publishing Co., Reston, Va.

Puustjarvi, V. 1983. Nature of changes in peat properties during decomposition. Peat and plant yearbook 1981-82. Peat Research Institute, Finland. p. 5-20.

Puustjarvi, V. and R.A. Robertson. 1975. Physical and chemical properties of peat, p. 24-36. In: D.W. Robinson and J.G.D. Lamb (eds.). Peat in horticulture. Academic Press, London.

SAS Institute. 1982. SAS user's guide and SAS statistical procedures. SAS Inst., Cary, N.C.

Van de Werken, H. 1989. A new way with containers. Amer. Nurseryman 170(2):43-51.

Warncke, D.D. 1986. Analyzing greenhouse growth media by the saturation extraction method. HortScience 21:223-225.

Warncke, D.D. and D.M. Krauskopf. 1983. Greenhouse growth media: Testing and nutrition guidelines. Michigan State Univ. Ext. Bul.E-1736.

Yelanich, M.V. and J.A. Biernbaum. 1993. Root-medium nutrient concentration and growth of poinsettia at three fertilizer concentrations and four leaching fractions. J. Amer. Soc. Hort. Sci. 118:771-776. 